\title{
In vitro analysis of shear bond strength and adhesive remnant index comparing light curing and self-curing composites
}

\author{
Murilo Gaby Neves¹, Gustavo Antônio Martins Brandão², Haroldo Amorim de Almeida², \\ Ana Maria Martins Brandão4, Dário Ribeiro de Azevedo ${ }^{5}$
}

Objective: To evaluate, in vitro, the shear bond strength of self-curing (Concise ${ }^{\mathrm{TM}}-3 \mathrm{M}$ and Alpha Plast $\left.-\mathrm{DFL}\right)$ and light-curing composites (Transbond ${ }^{\mathrm{TM}} \mathrm{XT}-3 \mathrm{M}$ and Natural Ortho - DFL) used in orthodontics bonding, associated to Morelli metal brackets, with further analysis of adhesive remnant index (ARI) and enamel condition in scanning electron microscopy (SEM). Methods: Forty human premolars, just extracted and stored in physiologic solution 0.9 $\%$ were used. Randomly, these samples were divided in four groups: G1 group, the brackets were bonded with Concise $^{\mathrm{TM}}-3 \mathrm{M}$ composite; in G2 group, Alpha Plast - DFL composite was used; in G3 group, Transbond ${ }^{\mathrm{TM}} \mathrm{XT}-3 \mathrm{M}$ was used; in G4 group, Natural Ortho - DFL composite was used. These groups were submitted to shear strength tests in universal testing machine, at $0.5 \mathrm{~mm}$ per minute speed. Results: Statistical difference between G3 and G4 groups was recorded, as G4 showing higher strength resistance than G3. In the other hand, there were no statistical differences between G1, G2 and G3 and G1, G2 and G4 groups. ARI analysis showed that there was no statistical difference between the groups, and low scores were recorded among then. The scanning electron microscopy (SEM) analysis revealed the debonding spots and the enamel surface integrity. Conclusions: Shear bond strength was satisfactory and similar between the composites, however Natural Ortho - DFL revealed best comparing to Transbond ${ }^{\mathrm{TM}} \mathrm{XT}-3 \mathrm{M}$. Keywords: Composite resins. Shear strength. Scanning electron microscopy.

Objetivo: avaliar in vitro a resistência ao cisalhamento de compósitos autopolimerizáveis (Concise e Alpha Plast) e fotopolimerizáveis (Transbond XT e Natural Ortho) utilizados na colagem de braquetes metálicos da marca Morelli, analisando o índice de adesivo remanescente (ARI) e da integridade da superfície do esmalte por meio de microscopia eletrônica de varredura (MEV). Métodos: foram utilizados 40 pré-molares humanos extraídos. As raízes dos dentes foram incluídas em gesso-pedra especial, no interior de tubos de PVC usados para a confecção dos corpos de prova. Esses corpos de prova foram divididos em quatro grupos: grupo G1, braquetes associados ao compósito Concise; grupo G2, braquetes associados ao compósito Alpha Plast; grupo G3, braquetes associados ao compósito Transbond XT; e grupo G4, braquetes associados ao compósito Natural Ortho. Os grupos foram submetidos ao teste de cisalhamento em máquina universal de ensaios, a uma velocidade de $0,5 \mathrm{~mm}$ por minuto. Resultados: houve diferença estatística entre os grupos G3 e G4, sendo os valores de G4 superiores; no entanto, não foram encontradas diferenças estatisticamente significativas entre os grupos G1, G2 e G3 e G1, G2 e G4. Na análise do ARI não foram encontradas diferenças estatísticas entre os grupos, predominando escores baixos. De acordo com a análise da MEV, constatou-se o rompimento dos compósitos e a integridade do esmalte entre os grupos. Conclusão: a resistência ao cisalhamento foi satisfatória e semelhante entre os compósitos utilizados, sendo que a resina Natural Ortho apresentou-se superior à Transbond XT.

Palavras-chave: Resinas compostas. Resistência ao cisalhamento. Microscopia eletrônica de varredura.

\footnotetext{
'Student of the Specialization Course in Orthodontics, Amazon Superior School.

${ }^{2} \mathrm{PhD}$ in Dentistry, UNICAMP.

${ }^{3} \mathrm{PhD}$ in Orthodontics, UNICAMP. Professor, School of Dentistry, Department of Orthodontics, UFPA.

${ }^{4} \mathrm{MSc}$ in Orthodontics, SLMandic. Professor, School of Dentistry, Department of Orthodontics, UFPA.

${ }^{5} \mathrm{MSc}$ in Dentistry, UNIP. Assistant Professor, Specialization Course in Orthodontics, UFPA.
}

Submitted: March 07, 2010 - Revised and accepted: December 17, 2010
How to cite this article: Neves MG, Brandão GAM, Almeida HA, Brandão AMM, Azevedo DR. In vitro analysis of shear bond strength and adhesive remnant index comparing light-curing and self-curing composites. Dental Press J Orthod. 2013 May-June;18(3):124-9.

» The authors report no commercial, proprietary or financial interest in the products or companies described in this article.

Contact address: Murilo Gaby Neves

Travessa Humaitá, 800 - Casa 06 - Pedreira

CEP: 66.085-220 - Belém/PA - Brazil

E-mail: murilo.orto@gmail.com 


\section{INTRODUCTION}

Orthodontics showed great strides with regard to the materials used for bonding orthodontic accessories to tooth from the 70's. ${ }^{19}$ Several bonding materials have been used, including composites which have good resistance, toughness and dimensional stability. ${ }^{8}$

Advantages to use light-curing resin in orthodontic procedures include reduced risk of contamination and increased accuracy in positioning the bracket, compared to the use of self-curing resin. However, this optimizes the clinical time by not requiring light cure action. ${ }^{21}$

It is not easy to quantify the ideal adhesive strength for bonding orthodontic accessories. It is known that there must not be extremely low or too high, so that the debonding does not cause fractures in the enamel surface. ${ }^{5}$ According to Bishara et al, ${ }^{2}$ to obtain a good result in orthodontic treatment, it is important after the removal of orthodontic brackets the enamel integrity is preserved. For Grandhi et $a l,{ }^{9}$ the ideal would be to minimize the loss of enamel in the bonding, debonding and removal of residual composite stages, remaining tooth surface with the original roughness degree of the tooth.

The evaluation of the enamel surface after debonding of orthodontic accessories may be accomplished by means of the adhesive remnant index (ARI), recommended by Årtun and Bergland. ${ }^{1}$ However in order to ratify the enamel damage caused by the resistance strength of the bracket, the Scanning Electron Microscopy (SEM) analysis can be used.,22

\section{MATERIAL AND METHODS}

For this experiment it was used 40 human upper premolars, free from cracks and fractures and freshly extracted for orthodontic reasons. After the extractions, teeth were washed, immersed and kept in plastic containers containing $50 \mathrm{ml}$ of $0.9 \%$ saline solution at room temperature. The use of teeth followed the guidelines of the Ministry of Health according to resolution 196/96 of National Health Council of 10/10/96 approved by the Ethics Committee of the Federal University of Pará - Approval No. $030 / 2008$. For the preparation of the specimens, the teeth roots were embedded in P.V.C. tubes (Tigre) with $25 \mathrm{~mm}$ of diameter / $25 \mathrm{~mm}$ of height, filled with special plaster stone (Durone - Dentsply). ${ }^{16}$ In the moment of the teeth insertion, the buccal surfaces were positioned perpendicular to the ground, using as an aid a juxtaposed square to the bonding surface and the excesses were removed with a spatula LeCron (Duflex). The specimens were stored again at $0.9 \%$ saline solution. ${ }^{18}$

The objective of this research was to evaluate the shear strength of the union of the bracket to the tooth, in the post fixation of 24 hours, comparatively using four resins: Two launched in the national market, Alpha Plast - DFL (self-curing) and Natural Ortho - DFL (light-curing), and two resins traditionally accepted as efficient, Concise ${ }^{\mathrm{TM}}$ Orthodontic - 3M (self-curing) and Transbond ${ }^{\mathrm{TM}} \mathrm{XT}-3 \mathrm{M}$ (self-curing); using the bracket marketed in Brazil (Morelli). After debonding of the bracket, the adhesive remnant index (ARI) will be evaluated and the enamel surface analysis will be performed in scanning electron microscopy (SEM).

The specimens were randomly divided into four groups of ten specimens. In the first group (G1) Morelli bracket was used with the Concise ${ }^{\mathrm{TM}}$ Orthodontic composite (self-curing); the second group (G2) Morelli bracket was associated with the Alpha Plast composite (self-curing); the third group (G3) Morelli bracket was associated with the Transbond ${ }^{\mathrm{TM}} \mathrm{XT}$ composite (light-curing); and the fourth group (G4) Morelli bracket was used with the Natural Ortho composite (light-curing).

In the buccal surface of the teeth was performed prophylaxis with pumice stone, rubber cup and water for 10 seconds; washing with air/water spray for 15 seconds and drying for 10 seconds. ${ }^{14}$ Then the etching was done with $37 \%$ phosphoric acid for 20 seconds, washing with air/water spray and drying for 20 seconds each. ${ }^{15}$ After, brackets were bonded following the manufacturer's instructions for each composite. Positioning of the bracket was done manually with forceps, and to standardize the application of force procedure was performed by a single operator.

The groups of specimens were subjected to shear bond strength test in universal testing machine (Kratos). The tests were conducted at 24 hours after bonding with of $0.5 \mathrm{~mm}$ per minute. The final results were obtained in Megapascal $(\mathrm{MPa})$ by the relationship of forces in Newton $(\mathrm{N})$ by the area of the brackets base used. 
After the shear bond strength test, the enamel surfaces of each specimen were classified according to the scores of the adhesive remnant index (ARI) proposed by Årtun and Bergland, ${ }^{1}$ being: Score $0=$ no amount of adhesive material adhered to the tooth; score $1=$ less than half of the adhesive material adhered to the tooth; score $2=$ more than half of the adhesive material adhered to the tooth; and score $3=$ all adhesive material adhered to the tooth, including bracket mesh impression. ${ }^{6}$

Representative samples of each type of ARI score were selected among the four groups, and suffered the gold metallization process. Then these samples were taken for SEM analysis. The teeth were displayed in their buccal surfaces in regions where the brackets were before the shear bond strength test. With illustrative purposes, the limits of fracture of composite and enamel surface were highlighted with 50 and $100 \mathrm{x}$ increases for each sample.

Analysis of variance (ANOVA) was used to compare differences between the groups in terms of mean of shear strength because the data is parametric and submit normality and equality of variances (homoscedasticity). To compare the rate of adhesive remnant index between the groups, varying the type of composite, the KruskalWallis test was used. In all statistical tests the significance level of $\alpha=5 \%$ was applied.

\section{RESULTS}

Table 1 presents the descriptive statistics data regarding the tension in Megapascal (MPa) (Table 1).

According to Analysis of Variance (ANOVA) for the shear bond strength test, we observed a statistically significant difference between groups $(\mathrm{p}=0.0355)$.

After performing the Tukey's multiple comparison tests, it was observed that the difference was between groups G3 and G4, and the group G4 showed statistically more resistant to shear than the G3. Other groups did not differ with respect to shear bond strength. All mean values of the tested groups represent bond strength greater than the consistent value with clinical needs in Orthodontics, ranging from 5.9 to $7.8 \mathrm{MPa}$ (Fig 1).

For the adhesive remnant index (ARI), after application of the Kruskal-Wallis test to compare the groups in relation to the amount of scores presented, it was realized that there is no statistically significant difference between groups $(p=0.9318)$ (Tables 2 and 3 ).

The results of photomicrographs of selected samples are presented in the following Figure 2. The images show the limits of fracture of correlate composites, sequentially to the four possible adhesive remnant index outcomes.

\section{DISCUSSION}

In orthodontic treatment using direct fixation composite must suit clinical needs, promoting sufficient bonding strength to carry out the procedures. Reynolds ${ }^{17}$ suggested a minimum bonding strength between 6 and $8 \mathrm{MPa}$. Values below this average are

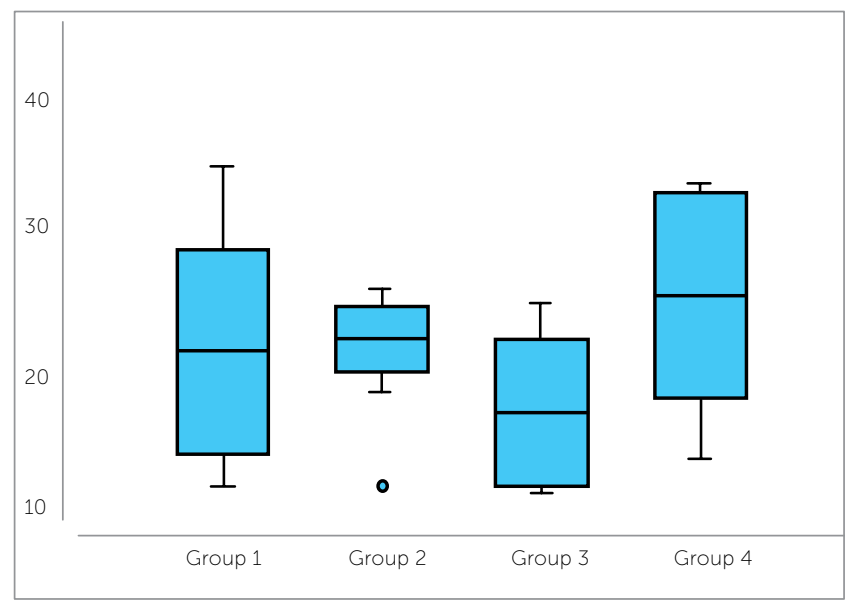

Figure 1 - Box-Plot representing the mean and standard deviation of the groups in relation to the tension applied in Megapascal (Mpa).

Table 1 - Descriptive Statistics regarding tension in Megapascal (Mpa)

\begin{tabular}{|c|c|c|c|c|}
\hline Sample Size & $\begin{array}{l}\text { G1: Concise }{ }^{\top M} \text { Orthodontic } \\
\qquad(n=10)\end{array}$ & $\begin{array}{l}\text { G2: Alpha Plast } \\
(n=10)\end{array}$ & $\begin{array}{l}\text { G3: TransbondTM } \\
(n=10)\end{array}$ & $\begin{array}{c}\text { G4-Natural Ortho } \\
(n=10)\end{array}$ \\
\hline Minimum & 11.5360 & 11.5360 & 10.9690 & 13.4930 \\
\hline Maximum & 36.4610 & 26.9340 & 25.8010 & 35.0880 \\
\hline Mean & 21.9662 & 21.7309 & 17.0855 & 26.3417 \\
\hline Standard Deviation & 7.9854 & 4.3439 & 5.8128 & 8.0216 \\
\hline
\end{tabular}


Table 2 - Descriptive statistics regarding the adhesive remnant index (scores).

\begin{tabular}{|c|c|c|c|c|}
\hline & G1: Concise ${ }^{\mathrm{TM}}$ 3M & G2: Alpha Plast DFL & G3: Transbond ${ }^{\mathrm{TM}} \mathrm{XT} 3 \mathrm{M}$ & C4: Natural Ortho DFL \\
\hline Minimum & 0.0000 & 0.0000 & 0.0000 & 0.0000 \\
\hline Maximum & 2.0000 & 1.0000 & 2.0000 & 3.0000 \\
\hline Mean & 0.7000 & 0.7000 & 0.6000 & 0.7000 \\
\hline Standard Deviation & 0.8233 & 0.4830 & 0.8433 & 0.9487 \\
\hline
\end{tabular}

Table 3 - Scores for adhesive remnant index from different groups.

\begin{tabular}{|c|c|c|c|c|}
\hline & G1: Concise ${ }^{\mathrm{TM}}$ Orthodontic & G2: Alpha Plast & G3: Transbond ${ }^{\mathrm{TM}} \mathrm{XT}$ & G4: Natural Ortho \\
\hline Specimen 1 & 2 & 1 & 1 & 0 \\
\hline Specimen 2 & 0 & 1 & 1 & 0 \\
\hline Specimen 3 & 0 & 1 & 0 & 0 \\
\hline Specimen 4 & 0 & 1 & 0 & 1 \\
\hline Specimen 5 & 1 & 1 & 2 & 3 \\
\hline Specimen 6 & 1 & 0 & 0 & 1 \\
\hline Specimen 7 & 2 & 0 & 2 & 0 \\
\hline Specimen 8 & 0 & 1 & 0 & 1 \\
\hline Specimen 9 & 0 & 1 & 0 & 0 \\
\hline Specimen 10 & 1 & 0 & 0 & 1 \\
\hline
\end{tabular}

synonymous with failure. As in other studies, all tests in the present study were higher than the average proposed. . $^{13,20,23}$

When comparing the resins, the statistical difference result between groups stands out. The analysis reveals that the G4 appeared more resistant to shear than G3. However, when comparing the groups G1, G2 and G3, and G1, G2 and G4 no statistically significant differences were found between them (Fig 1).

These findings are similar to Mondelli and Fei$\operatorname{tas}^{11}$ and Valletta et al, ${ }^{24}$ but confront with the results obtained from Giannini and Francisconi ${ }^{7}$ research, wherein the Concise ${ }^{\mathrm{TM}}$ orthodontic composite appeared stronger than Transbond ${ }^{\mathrm{TM}}$ XT composite.

For the Alpha Plast and Natural Ortho composites, no evident research was found in the literature. Both materials are newly available and inexpensive when compared to Concise ${ }^{\mathrm{TM}}$ orthodontic and Transbond $^{\mathrm{TM}} \mathrm{XT}$ composites, universally accepted by science as materials of excellence for clinical use. However, these new composite proved as highly resistant to shear.

This research also analyzed the adhesive remnant index (ARI), proposed by Årtun and Bergland. ${ }^{1}$

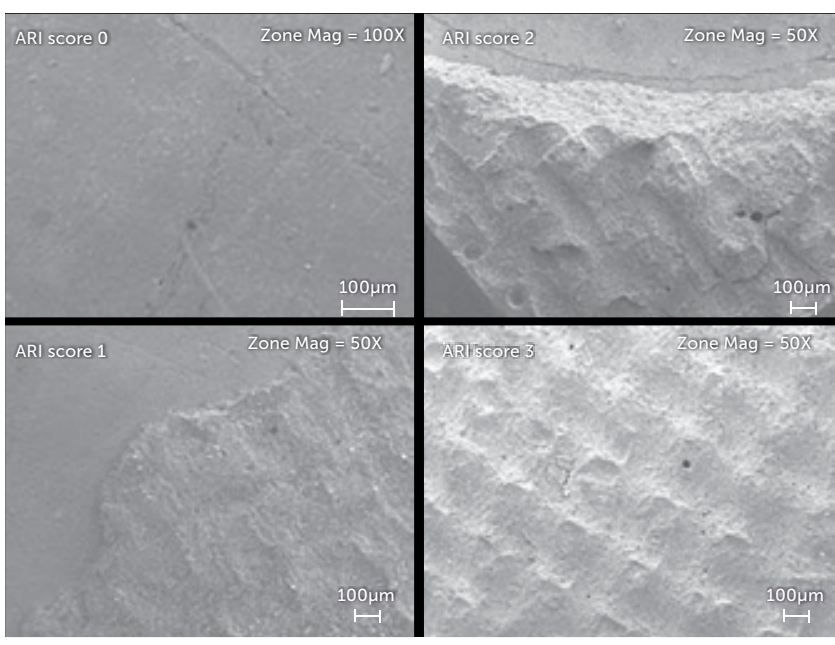

Figure 2 - Representative specimens for ARI, subjected to SEM increase.

The classification of the composite amount adhered to the tooth, after removing the bracket suggests degrees of susceptibility to enamel fracture. To maintain the integrity of the enamel, the ideal is to achieve high scores on the ARI, i.e. greater amount of material adhered to the tooth. This avoids a situation where there is disruption of hydroxyapatite crystals in enamel. Moreover, these composite may be easily removed with finishing burs, without any damage to enamel. 
The results of this research revealed predominantly low scores for all groups, and the comparison between showed no statistically significant difference (Tables 2 and 3 ).

For ARI to the Concise ${ }^{\mathrm{TM}}$ orthodontic (G1) and Transbond ${ }^{\mathrm{TM}} \mathrm{XT}(\mathrm{G} 3)$ resins, the results reinforce the research of Derech et al, ${ }^{5}$ Montasser et al, ${ }^{12}$ and Penido et $\mathrm{al}^{4}$ who also obtained low scores. On the other hand, our results confront studies which reported the majority of disruptions in the interface composite/ bracket. ${ }^{4,15,16,19,24}$

After shear bond strength test and during the ARI evaluation enamel fractures were observed in four specimens distributed among the four groups. This relative frequency of fractures among groups, supported by the study by Liu et al, ${ }^{10}$ may be associated with high strength supported by the samples.

These findings are conflicting when compared to those obtained by Mondelli and Feitas, ${ }^{11}$ who claim that the weakest link in the orthodontic bonding is in the interface composite/bracket, reiterating that the adhesive interface is critical in terms of resistance.

Despite the lack of comparison parameters in literature, it must ratify the results for Alpha Plast and Natural Ortho composites behaved similar to Concise ${ }^{\mathrm{TM}}$ orthodontic and Transbond ${ }^{\mathrm{TM}}$ XT composites, for ARI.

SEM photomicrographs allowed most accurate view of the enamel surface and the of composite fracture areas.
These same features enabled Stratmann et a ${ }^{22}$ estimate risk of enamel fracture between $23 \%$ and $63 \%$ of specimens associated with Concise ${ }^{\mathrm{TM}}$ orthodontic composite. In the study by Chen et $\mathrm{al}^{3}$ in which metallic brackets are fixed with the composite Transbond ${ }^{\mathrm{TM}} \mathrm{XT}$, it was observed enamel fractures in $40 \%$ of samples.

Impartiality business is one of the requirements of this study, so our purpose is to highlight, through testing, specific characteristics of these composites. It is noteworthy that all tested products are fully suitable for clinical use, with the primary objective of maintaining the integrity of the enamel.

\section{CONCLUSION}

It was concluded that all composites, both self-curing and light-curing, used in this study exhibited good strength and similar results. Natural Ortho composite presented higher strength in comparison to Transbond $^{\mathrm{TM}}$ XT composite.

Regarding the adhesive remnant index (ARI), there was a predominance of low scores between the groups, showing little or no amount of resin bonded to enamel.

With the illustrative results of the enamel surface by scanning electron microscopy (SEM), it was ratified the amount of material adhered to the tooth of selected samples, besides the need to display the limits of composite fracture. 


\section{REFERENCES}

1. Artun J, Bergland S. Clinical trials with crystal growth conditioning as an alternative to acid-etch enamel pretreatment. Am J Orthod. 1984;85(4):333-40

2. Bishara SE, Ajlouni R, Laffoon JF, Warren JJ. Effect of a flouride-releasing self-etch acidic primer on the shear bond strength of orthodontic brackets. Angle Orthod. 2002;72(3):199-202.

3. Chen CS, Hsu ML, Chang KD, Kuang SH, Chen PT, Gung YW. Failure analysis: enamel fracture after debonding orthodontic brackets. Angle Orthod. 2008:78(6):1071-7.

4. Cozza P, Martucci L, De Toffol L, Penco SI. Shear bond strength of metal brackets on enamel. Angle Orthod. 2006;76(5):851-6.

5. Derech CA, Pereira JS, Souza MMG. $O$ efeito do jateamento do esmalte na força de adesão na colagem de bráquetes. Rev Dental Press Ortod Ortop Facial. 2008:13(3):43-9.

6. Falcão CB, Brito AM, Ahid FJM. Avaliação da influência dos tipos de tratamento superficial da porcelana glazeada na colagem de braquetes ortodônticos. Rev Dental Press Ortod Ortop Facial. 2009;14(3):102-6.

7. Giannini C, Francisconi PAS. Resistência à remoção de bráquetes ortodônticos sob ação de diferentes cargas contínuas. Rev Dental Press Ortod Ortop Facial. 2008:13(3):50-9.

8. Gorelik L. Bonding metal brackets with a self-polymerizing sealant composite: a 12 month assessment. Am J Orthod. 1977;71(5):542-53.

9. Grandhi RK, Combe EC, Speidel TM. Shear bond strength of stainless steel orthodontic brackets with a moisture insensitive primer. Am J Orthod Dentofacial Orthop. 2001;119(3):251-5.

10. Liu JK, Chang LT, Chuang SF, Shieh DB. Shear bond strengths of plastic brackets with a mechanical base. Angle Orthod. 2002;72(2):141-5.

11. Mondelli AL, Feitas MR. Estudo comparativo da resistência adesiva da interface resina / bráquete, sob esforços de cisalhamento, empregando três resinas compostas e três tipos de tratamento na base do bráquete. Rev Dental Press Ortod Ortop Facial. 2007;12(3):111-25.

12. Montasser MA, Drummond JL, Evans CA. Rebonding of orthodontic brackets. Angle Orthod. 2008;78(3):537-44.

13. Moura WL, Moreira TCA, Teles JBM. Avaliação da resistência à tração de artificios ortodônticos - bráquete, botão e tela - colados em pré-molares com resina autopolimerizável. Estudo "in vitro". Rev Dental Press Ortod Ortop Facial. 2004;9(3):110-5.

14. Penido SMMO, Penido CVSR, Santos-Pinto A, Sakima T, Fontana CR. Estudo in vivo e in vitro com e sem termociclagem, da resistência ao cisalhamento de bráquetes colados com fonte de luz halógena. Rev Dental Press Ortod Ortop Facial. 2008;13(3):66-76
15. Pithon MM, Santos RL, Oliveira MV, Ruellas ACO. Estudo comparativo in vitro da resistência ao cisalhamento da colagem e do índice de remanescente adesivo entre os compósitos Concise e Fill Magic. Rev Dental Press Ortod Ortop Facial. 2006:11(4):76-80.

16. Pithon MM, Bernardes LAA, Ruellas ACO, Romano FL. Avaliação da resistência ao cisalhamento do compósito Right-On em diferentes condições de esmalte. Rev Dental Press Ortod Ortop Facial. 2008:13(3):60-5

17. Reynolds IR. A review of direct orthodontic bonding. Br J Orthod 1975:2(2):171-8.

18. Romano FL, Ruellas ACO. Estudo Comparativo in vitro da resistência ao cisalhamento da colagem e do índice de remanescente resinoso entre os compósitos Concise e Superbond. Rev Dental Press Ortod Ortop Facial. 2003:8(1):69-75

19. Romano FL, Tavares SW, Ramalli EL, Magnani MBBA, Nouer DF. Análise in vitro da resistência ao cisalhamento de braquetes metálicos colados em incisivos bovinos e humanos. Rev Dental Press Ortod Ortop Facial. 2004; 9(6):63-9.

20. Rosa CB, Pinto RAC, Habib FAL. Colagem ortodôntica em esmalte com presença ou ausência de contaminação salivar: é necessário o uso de adesivo auto-condicionante ou de adesivo hidrofílico? Rev Dental Press Ortod Ortop Facial. 2008;13(3):34-42

21. Sfondrini MF, Cacciafesta V, Pistorio A, Sfondrini G. Effects of conventional and high-intensity lightcuring on enamel shear bond strength of composite resin and resin-modified glass-ionomer. Am J Orthod Dentofacial Orthop. 2001:119(1):30-5

22. Stratmann $U$, Schaarschmidt $K$, Wegener $H$, Ehmer U. A quantitative comparison of thermally debonded ceramic and mechanically debonded metal brackets by energy dispersive micro- and image-analysis. Eur J Orthod. 1996:18(6):655-62

23. Thys DG, Lopes GC, Derech CD, Locks A, Vieira LCC. Avaliação do comportamento de sistemas adesivos, hidrófilo e hidrófobo, na adesão de "brackets" ao esmalte contaminado por sangue. Rev Dental Press Ortod Ortop Facial. 2003:8(4):45-50

24. Valletta R, Prisco D, De Santis R, Ambrosio L, Martina R. Evaluation of the debonding strength of orthodontic brackets using three different bonding systems. Eur J Orthod. 2007:29(6):571-7. 